\title{
LENGTH RECORD OF THE BEAKED WORM SNAKE (RHINOTYPHLOPS ACUTUS) AND ITS DISTRIBUTION IN GUJARAT
}

\author{
Raju Vyas ${ }^{1}$, Karmavir Bhatt ${ }^{2}$ and Indra Gadhvi ${ }^{3}$ \\ ${ }^{1}$ Sayaji Baug Zoo, Vadodara, Gujarat 390018, India. \\ ${ }^{2}$ B/802, Sejal Appartment, City Light Society Road, Parale Point, Surat, \\ Gujarat, India. \\ ${ }^{3}$ Lecturer, Zoology Department, Sir P.P. Science College, Bhavnagar, \\ Gujarat 364001, India.
}

On 12 November 1999, after our visit to Purna Wildlife Sanctuary, Dangs District (20 $51^{\prime}-21^{\prime} \mathrm{N}$ latitude and $73^{\circ} 32^{\prime}-73^{\circ} 48^{\prime}$ E longitude) we passed through Duldha to Bandhpada Village on foot, at 0700 hrs. On the way we saw a long dead snake (road kill) on the road near a silvicultural plot. After carefully examination, it was identified as Beaked Worm Snake Rhinotyphlops acutus (Bibron \& Duméril, 1803). Its measurements and other details are as follows.

Snout to vent length $623.92 \mathrm{~mm}$, vent to tip of tail length $7.08 \mathrm{~mm}$,

total body length $631.00 \mathrm{~mm}$, and mid-body girth $11.30 \mathrm{~mm}$. Costal 28 at mid-body, dorsal scales little larger than the laterals and ventrals. Dorsal body colour dark brown and belly light pale brown with large pointed beaked shape rostral and posterior extend above the eye level; a long, narrow nasal and a preocular.

According to Smith (1943) the species is distributed in India from south of Ganges Basin and south of Rajputana (Rajasthan), west of Baroda (Vadodara) and east to Calcutta. Rare, south of latitude 16 seems to be rather uncertain. Published literature has revealed the fact that the species has been reported with certainity from the state of Gujarat (Daniel \& Shull, 1963; Sharma, 1982; Gayen, 1999), Madhya Pradesh, Maharashtra, West Bengal, Bihar, Orissa, Andhra Pradesh, Tamil Nadu and Kerala (Murthy, 1995).

During study of reptilian fauna, we recorded this species from different localities of the state such as Bhavnagar City, Bhavnagar District; Saputara, Dangs District; Navtad (Vansda National Park), Navsari District and Valabh Vidhya Nagar, Anand District. In addition, this species was recorded from Surendranagar (Sharma, 1982), Ahmedabad, Ahmedabad District (Gayen, 1999) and Barda Wildlife Sanctuary, Porbander District (Ketan Bhalodia, pers. comm.). Present records of the species from different locations of Gujarat, indicate that the species is widely distributed in the state (Fig. 2).

\section{Acknowledgement}

We thank Ketan Bhalodia for providing information on the

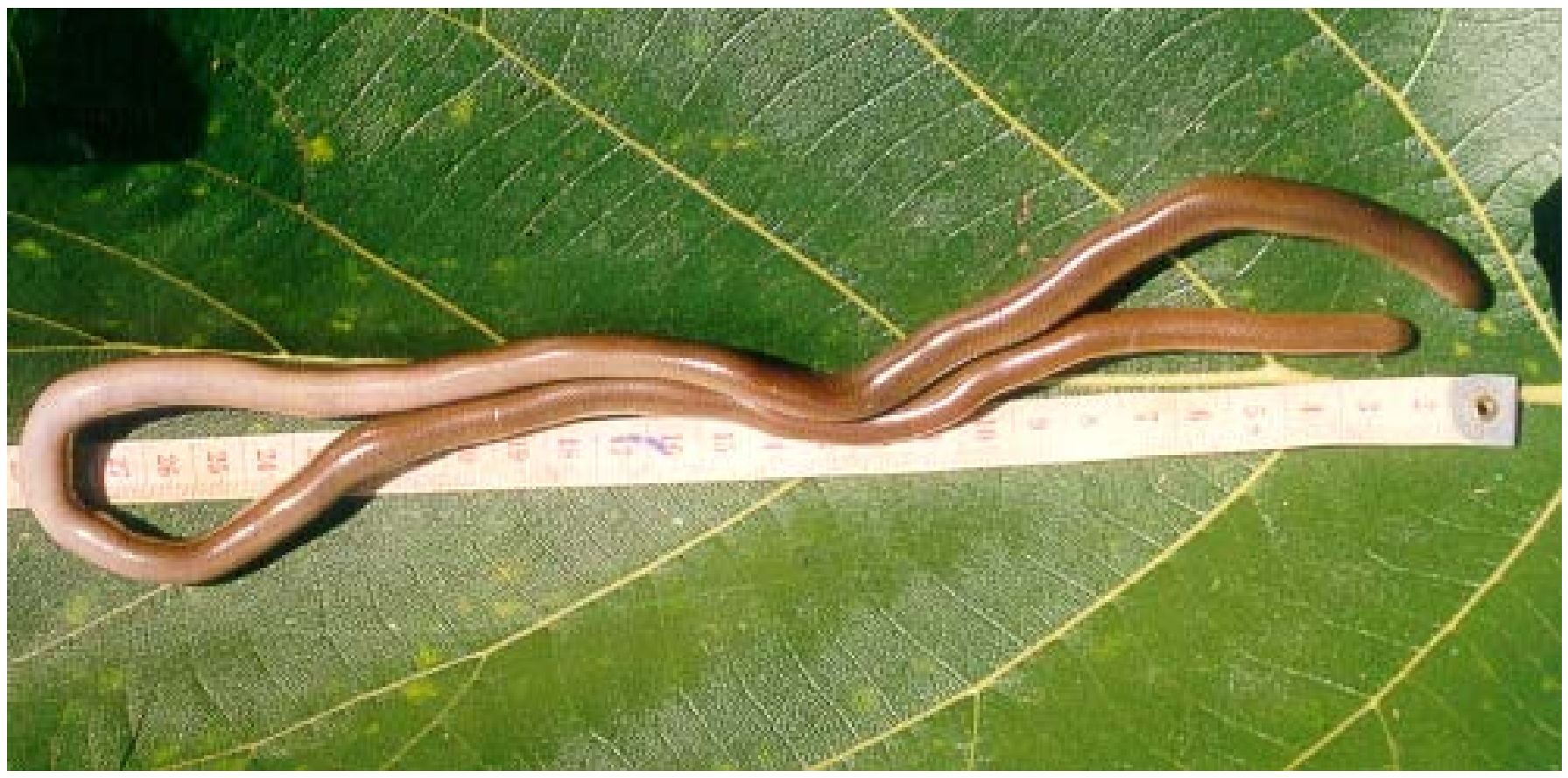

Figure 1. Longest Beaked Worm Snake Rhinotyphlops acutus from Duldha, Dangs, Gujarat 


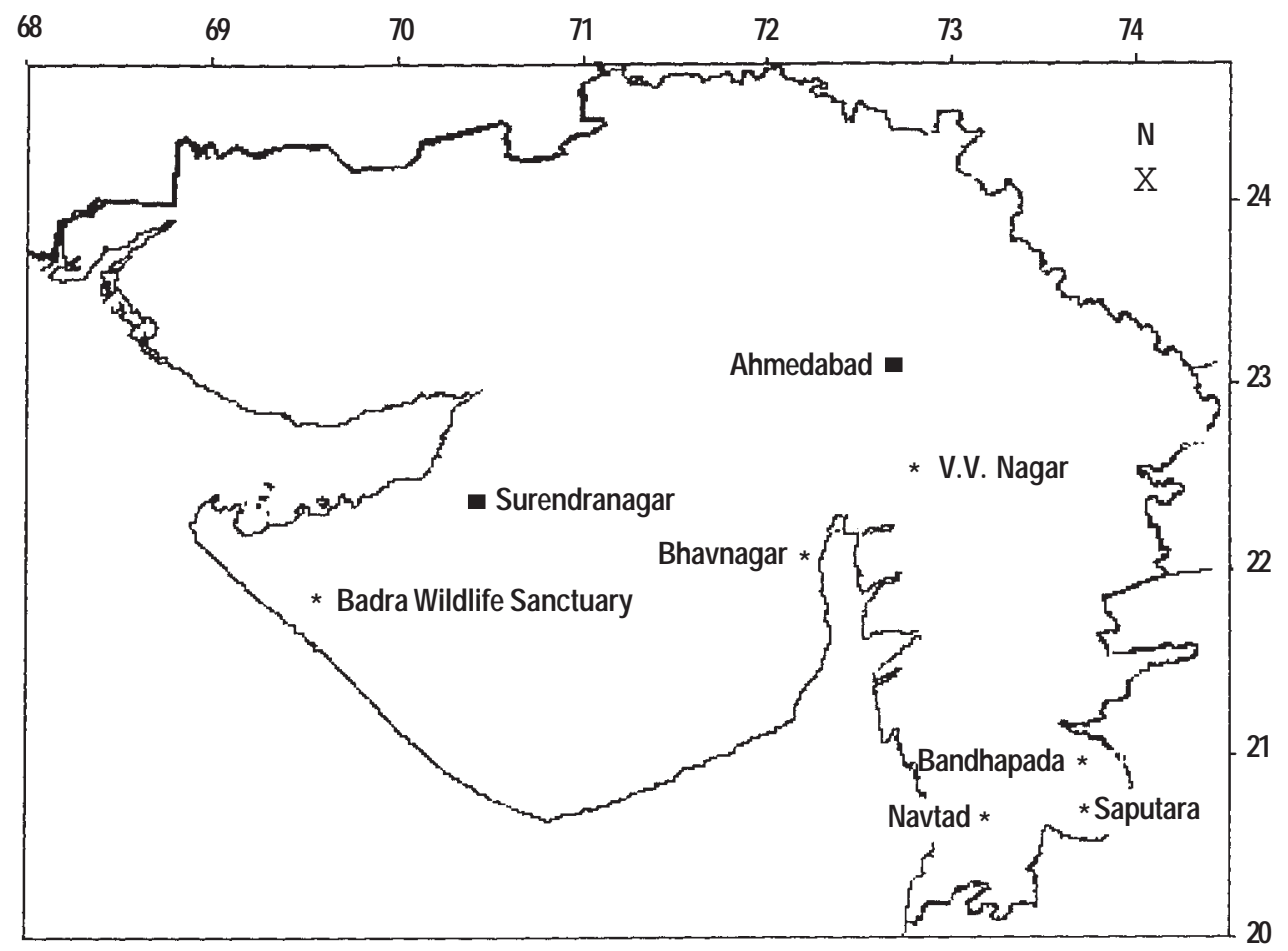

* Present record; $\boldsymbol{\square}$ Past record

Figure 2. Map of Gujarat showing recorded sites of Rhinotyphlops acutus

Table 1. Measurements ( $\mathrm{mm}$ ), collection date and locality information of Beaked Worm Snake (Rhinotyphlops acutus) from Gujarat State.

\begin{tabular}{lllllllll}
\hline DOC & Locality & SVL & TL & TBL & MBG & SR & TBL/MG & TBL/TL \\
\hline 4.06 .1999 & $\begin{array}{l}\text { Bhavnagar, } \\
\text { Bhavnagar District }\end{array}$ & 316.86 & 03.14 & 320.0 & 04.52 & 28 & 70.79 & 101.91 \\
12.11 .1999 & $\begin{array}{l}\text { Bandhpada, } \\
\text { Dangs District }\end{array}$ & 623.92 & 07.08 & 631.1 & 11.30 & 28 & 55.84 & 89.12 \\
10.08 .1999 & $\begin{array}{l}\text { Navtad, Vansda, } \\
\text { Navsari District } \\
06.12 .1987\end{array}$ & - & - & $14.5^{*}$ & - & - & - & - \\
& $\begin{array}{l}\text { Saputara, } \\
\text { Dangs District }\end{array}$ & 548.50 & 06.50 & 555.0 & 08.00 & 28 & 69.37 & 85.38 \\
\hline
\end{tabular}

SVL - Snout to vent length; TL - Tail length; TBL - Tail body length; MBG - Mid-body girth; SR - Scale rows * Killed found on road.

species and material examination.

\section{References}

Daniel, J.C. and E.M. Shull (1963). A list of the reptiles and amphibians of Surat, Dangs, South Gujarat. Journal of the Bombay Natural History Society 60: 737-743.

Gayen, N.C. (1999). A synopsis of the reptiles of Gujarat, western India. Hamadryad 24(1): 1-22.
Murthy, T.S.N. (1995). Fauna of Chilka lake, Wetland Ecosystem Series 1. Zoological Survey of India: 507-560.

Sharma, R.C. (1982). Taxonomic and ecological studies on the reptiles of Gujarat. Records of the Zoological Survey of India 80: 85-108.

Smith, M.A. (1943). The Fauna of British India including Ceylon and Burma: Reptilia and Amphibia, Vol. III-Serpentes. Taylor and Francis Limited, London, xii + 1583 pp. 